\title{
CBCT-guided management of compound odontome
}

\author{
Senthil Kumar Marappa Sathyamoorthy (1) , ${ }^{1}$ Harini Chakrika, ${ }^{2}$ \\ Murugesan Dhinakaran ${ }^{3}$
}

${ }^{1}$ Oral and Maxillofacial Surgery, Sri Ramakrishna Dental College and Hospital, Coimbatore,

Tamilnadu, India

${ }^{2}$ Sri Ramakrishna Dental College and Hospital, Coimbatore,

Tamilnadu, India

${ }^{3}$ Dentist Corner, Coimbatore,

Tamil Nadu, India

\section{Correspondence to}

Dr Senthil Kumar Marappa Sathyamoorthy:

senthilkumarmds@gmail.com

Accepted 27 August 2021

\section{DESCRIPTION}

Unerupted permanent maxillary incisors pose significant aesthetic and functional problems, thereby requiring comprehensive treatment. The prevalence of non-eruption of permanent incisors is $2 \%$, often involving the maxillary central incisors $(\sim 70.6 \%){ }^{1}$ A major cause for impaction of maxillary incisors is the obstruction of eruption by supernumerary teeth and odontomes, while other causes include developmental dental anomalies and ectopic positioning of tooth buds. Odontomes, being the most common odontogenic tumours, are dental hamartomas that constitute $22 \%$ of benign odontogenic tumours. ${ }^{2}$ Though odontomes are mostly asymptomatic, they may present with altered tooth eruption patterns and non-vitality of adjacent teeth or may become symptomatic following local infection. Broadly, odontomes are classified into compound and complex types, with compound odontomes further classified into denticular, particulate and denticuloparticulate types. ${ }^{2}$ They are rarely associated with syndromes like Gardner's syndrome and Hermann's syndrome. ${ }^{3}$ Ideal management of odontomes involves removal of the obstructing odontome without disturbing the follicle to allow spontaneous eruption of the impacted tooth. This is generally observed in teeth with incomplete apex formation. If the tooth fails to erupt after 12 months, the tooth is exposed, and eruption is facilitated via bonded brackets. ${ }^{4}$

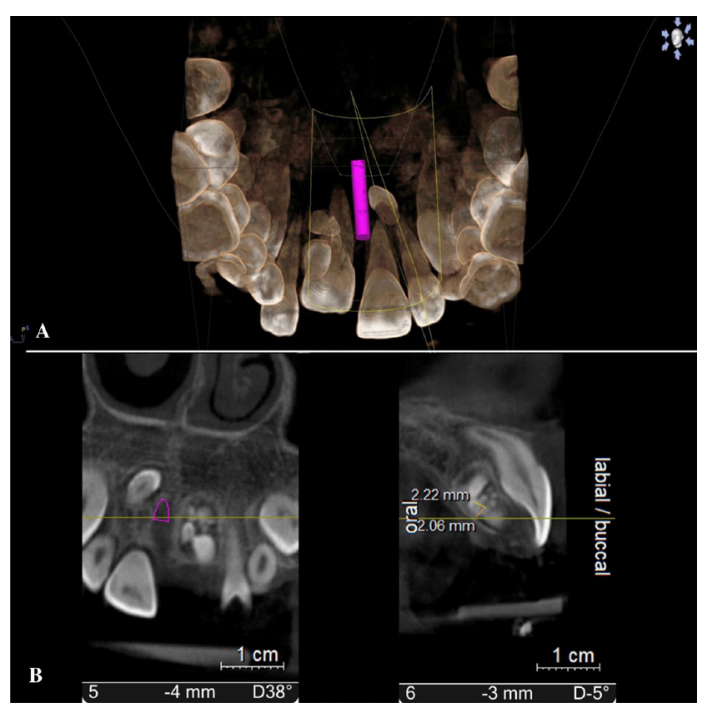

Figure 1 (A) CBCT for three-dimensional localisation of the odontome and supernumerary tooth; (B) coronal and sagittal views showing palatal positioning of the odontome and supernumerary tooth.

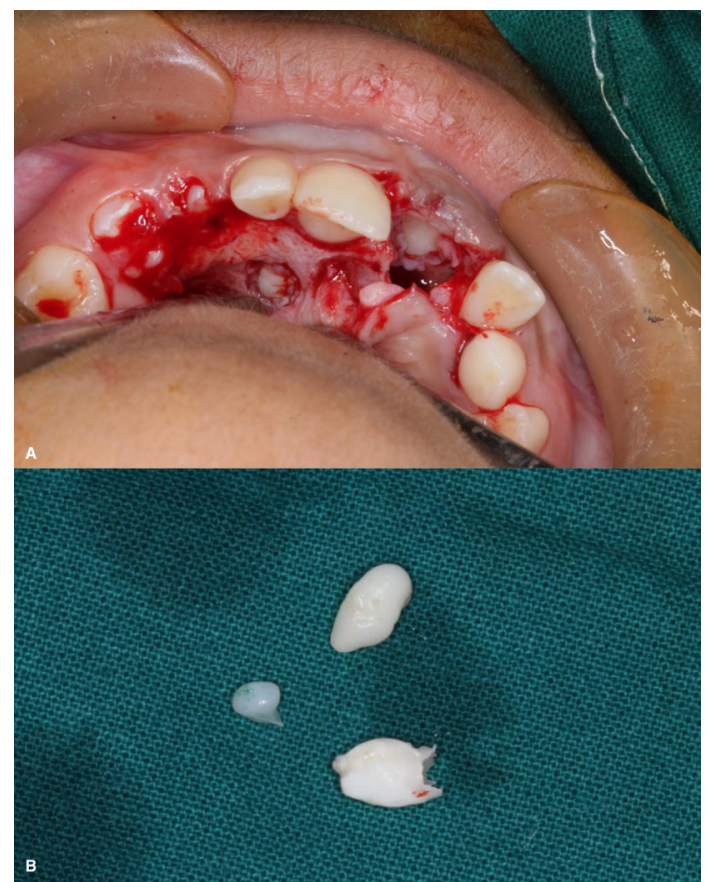

Figure 2 (A) Surgical removal of the odontome and supernumerary tooth; (B) extracted denticles resembling normal tooth architecture.

An 11-year-old male patient reported to the dental clinic with the chief complaint of non-eruption of the upper left front tooth. No relevant medical, dental and family histories were reported. Extraoral examination revealed no significant findings, while intraoral examination revealed missing \#21 with no other hard tissue abnormalities. No signs of swelling or inflammation were found on soft tissue examination. CBCT imaging was advised, which revealed the aetiology for non-eruption of \#21 to be the presence of compound odontome (figure 1). An impacted supernumerary tooth with incomplete root formation was seen on the palatal aspect, at the level of apices of \#11 and \#12. Multiple radiopaque structures bearing minimal resemblance to tooth structure were seen on the palatal aspect of

\section{Patient's perspective}

My son wasn't able to pronounce words clearly and never fully smiled due to his missing front tooth. Seeing other children his age have both front teeth, we decided to visit the dentist for a consultation. Once the extra teeth were removed, a new tooth erupted in a few months to fill the gap. My child can smile happily again! 
the arch in relation to the apical and middle third of root of \#22, suggestive of compound odontome. Differential diagnoses considered include fibro-osseous lesions, ameloblastic odontoma and adenomatoid odontogenic tumour.

A full-thickness palatal flap was raised following administration of local anaesthesia, and guttering of palatal bone was done to expose the impacted rudimentary tooth and compound odontome for its surgical removal (figure 2). Since \#21 had an immature apex, follow-up after 6 months

\section{Learning points}

- CBCT imaging plays a key role in the localisation of odontomes and subsequent treatment planning.

- Early management of impacted anterior teeth is crucial to avoid dental complications like loss of space and midline shift.

- Typically, the impacted maxillary incisors erupt spontaneously following removal of the obstruction, eliminating the need for complex treatment procedures.

- A higher incidence of cystic changes and resorption of roots of adjacent teeth are observed in case of delayed treatment. revealed spontaneous eruption of the tooth with no subsequent complications.

Twitter Senthil Kumar Marappa Sathyamoorthy @senthil1035

Contributors SKMS and MD contributed to patient treatment, conception and design. HC and SKMS contributed to drafting the work, literature review and manuscript editing.

Funding The authors have not declared a specific grant for this research from any funding agency in the public, commercial or not-for-profit sectors.

Competing interests None declared.

Patient consent for publication Parents/guardian consent obtained.

Provenance and peer review Not commissioned; externally peer reviewed.

\section{ORCID iD}

Senthil Kumar Marappa Sathyamoorthy http://orcid.org/0000-0002-4115-0449

\section{REFERENCES}

1 Tan C, Ekambaram M, Yiu CKY. Prevalence, characteristic features, and complications associated with the occurrence of Unerupted permanent incisors. PLoS One 2018;13:e0199501.

2 Satish V, Prabhadevi MC, Sharma R. Odontome: a brief overview. Int J Clin Pediatr Dent 2011:4:177-85.

3 Gedik R, Müftüoğlu S. Compound Odontoma: differential diagnosis and review of the literature. West Indian Med J 2014:63:793-5.

4 Seehra J, Yaqoob O, Patel S, et al. National clinical guidelines for the management of Unerupted maxillary incisors in children. Br Dent J 2018;224:779-85.

Copyright 2021 BMJ Publishing Group. All rights reserved. For permission to reuse any of this content visit

https://www.bmj.com/company/products-services/rights-and-licensing/permissions/

BMJ Case Report Fellows may re-use this article for personal use and teaching without any further permission.

Become a Fellow of BMJ Case Reports today and you can:

- Submit as many cases as you like

- Enjoy fast sympathetic peer review and rapid publication of accepted articles

- Access all the published articles

Re-use any of the published material for personal use and teaching without further permission

Customer Service

If you have any further queries about your subscription, please contact our customer services team on +44 (0) 2071111105 or via email at support@bmj.com.

Visit casereports.bmj.com for more articles like this and to become a Fellow 